\title{
APLIKASI ABSENSI SISWA ANDROID SMP NEGERI 11 BANJARMASIN BERBASIS QUICK RESPONSE (QR) KODE
}

\author{
Herry Adi Chandra') , Yusup Indra Wijaya ${ }^{2)}$, Dwi Agung Wibowo ${ }^{3)}$ \\ ${ }^{1}$ Fakultas Teknologi Informasi Universitas Islam Kalimantan Muhammad Arsyad Al Banjari Banjarmasin \\ email: herrysbc@gmail.com \\ ${ }^{2}$ Fakultas Teknologi Informasi Universitas Islam Kalimantan Muhammad Arsyad Al Banjari Banjarmasin \\ email: yusupindra1313@gmail.com \\ ${ }^{3}$ Fakultas Teknologi Informasi Universitas Islam Kalimantan Muhammad Arsyad Al Banjari Banjarmasin \\ email: agungfti@gmail.com
}

\begin{abstract}
Abstrak
Dimasa ini sistem absensi siswa di sekolah masih didominasi dengan cara manual, yaitu melakukan absensi siswa dengan mencatatnya di kertas yang nantinya akan direkap dari setiap data hadir siswa. Karena rekap data hadir siswa yang dilakukan secara manual rentan terjadi kesalahan karena mudah dimanipulasi oleh siswa yang tidak hadir. Informasi seputar rekap absensi hanya terbatas untuk pihak sekolah saja sehingga orang tua/wali murid tidak bisa memantau tingkat kehadiran siswa. Pihak sekolah pun dapat mengalami resiko kehilangan data absensi siswa yang terkadang terselip dengan berkas lain. Hal ini perlu adanya solusi untuk mengatasi masalah tersebut, maka dirancanglah sebuah sistem aplikasi absensi siswa menggunakan kode QR (QR Kode) berbasis android di SMP Negeri 11 Banjarmasin. Dengan aplikasi ini guru dapat melakukan absensi siswa melalui kode QR yang tertera pada kartu pelajar menggunakan smartphone android sebagai pembaca kode $\mathrm{QR}$, sehingga guru tidak perlu lagi mencatat absensi siswa secara manual. Jadi guru dapat meminimalisir resiko kehilangan data absensi siswa yang biasanya terselip dengan berkas lain, selain itu data absensi siswa bisa diolah dan direkap oleh pihak sekolah yang kemudian data tersebut akan dikirim ke setiap orang tua/wali murid melalui E-mail.
\end{abstract}

Kata Kunci : Aplikasi Absensi, Android, Qr Kode

\section{PENDAHULUN}

\subsection{Latar Belakang}

Pada saat ini absensi siswa pada sekolah masih didominasi dengan cara manual, yaitu melakukan abseni siswa dengan mencatatnya di kertas yang nantinya akan direkap dari setiap data hadir siswa. Karena rekap data hadir siswa yang dilakukan secara manual juga mempengaruhi informasi tentang rekap absensi masih terbatas untuk pihak sekolah saja, sehingga orang tua/wali murid tidak dapat memantau tingkat kehadiran siswa. Guru juga dapat mengalami resiko kehilangan data absensi siswa yang terkadang terselip dengan berkas lain.
Untuk membantu mengatasi masalah tersebut, dirancang sebuah sistem aplikasi absensi siswa menggunakan kode QR (QR Kode) berbasis android di SMP Negeri 11 Banjarmasin. Dengan aplikasi ini guru dapat melakukan absensi siswa melalui kode QR yang tertera pada kartu pelajar menggunakan smartphone android sebagai pembaca kode QR, sehingga guru tidak perlu lagi mencatat absensi siswa secara manual. Jadi guru bisa meminimalisir resiko kehilangan data absensi siswa yang biasanya terselip dengan berkas lain, setelah itu data tersebut bisa diolah dan direkap oleh pihak sekolah yang kemudian data absensi siswa akan dikirim ke setiap orang tua/wali murid melalui E-mail. Setiap Guru memiliki 
akun sebagai keamanan data untuk mengoperasikan aplikasi absensi siswa dengan menggunakan smartphone android.

\subsection{Rumusan Masalah}

Perlu suatu langkah untuk mempermudah kegiatan absensi siswa pada SMP Negeri 11 Banjarmasin tersebut maka rumusan masalah yang akan diuraikan pada penelitian ini yaitu bagaimanakah aplikasi absensi siswa dengan menggunakan smartphone android pada SMP Negeri 11 Banjarmasin dapat mengurangi resiko kehilangan data absensi siswa yang terkadang terselip dengan berkas lain dan memberi kemudahan pada sekolah dalam melaksanakan proses belajar-mengajar.

\subsection{Tujuan dan Target Luaran}

Tujuan dari penelitian ini adalah membuat suatu sistem aplikasi presensi siswa menggunakan kode QR (QR Code) berbasis android di SMP Negeri 11 Banjarmasin. Adapun manfaat yang diharapkan yaitu : dengan dibuatnya aplikasi ini diharapkan dapat mengurangi resiko kehilangan data absensi siswa yang terkadang terselip dengan berkas lain dan memberi kemudahan pada sekolah dalam melaksanakan proses belajar-mengajar.

Target luaran yang ingin dicapai oleh kami adalah Penelitian ini bisa masuk Prosiding Jurnal UNISKA .

\section{METODE PENELITIAN}

Tahapan Pengumpulan Data

Untuk memperoleh data yang diperlukan dalam penyusunan penelitian ini dengan menggunakan metode pengumpulan data sebagai berikut:

a. Wawancara atau interview

Wawancara adalah suatu metode yang digunakan untuk memperoleh data dengan cara mengajukan pertanyaan-pertanyaan secara langsung. Dalam hal ini kami akan melakukan wawancara secara langsung dengan pihak SMP Negeri 11 Banjarmasin.

b. Pengamatan Langsung atau Observasi.

Observasi adalah metode pengumpulan data dengan cara mengamati secara langsung proses penerimaan siswa baru pada SMP Negeri 11 Banjarmasin.

c. Studi Pustaka
Studi pustaka adalah suatu metode pengumpulan data dengan menggunakan buku-buku dan pencarian di internet sebagai bahan referensi dalam penulisan penelitian dan pembuatan sistem.

Untuk analisa Kebutuhan sistem aplikasi absensi siswa menggunakan kode QR (QR Code) berbasis android di SMP Negeri 11 Banjarmasin yang akan dibuat nanti diharapkan dapat menyelesaikan masalah-masalah yang dihadapi. Dengan demikian akan membuat beberapa menu guna mempermudah dalam sistem kerja dan agar dapat melangsungkan pengetesan secara baik, serta kebutuhan yang sesuai dengan keinginan.

Menu yang ada di aplikasi diantaranya adalah

- Menu Log In Admin

- Menu pilih kelas

- Scan Absensi

- E-Mail Orang tua/Wali muid

\section{HASIL DAN PEMBAHASAN}

\section{Tahapan Pembuatan}

Pembuatannya adalah membuat suatu sistem aplikasi absensi siswa menggunakan kode QR (QR Code) berbasis android di SMP Negeri 11 Banjarmasin dapat mengurangi resiko kehilangan data absensi siswa yang terkadang terselip dengan berkas lain dan memberi kemudahan pada sekolah dalam melaksanakan proses belajar-mengajar.

Use case diagram adalah diagram yang membantu dalam menyusun requirement sebuah sistem, mengkomunikasikan rancangan dengan klien, dan merancang test case untuk semua fitur yang ada pada sistem. Use case diagram menggunakan fungsionalitas yang diharapkan dari sebuah sistem. Use case diagram menekankan apa yang dibuat sistem, dan bukan bagaimana sebuahUse case diagram menekankan apa yang dibuat sistem, dan bukan bagaimana. Sebuah use case merepresentasikan sebuah interaksi antara actor dengan sistem aplikasi presensi siswa menggunakan kode QR (QR Code) berbasis android adalah seperti pada diagram berikut 


\section{Tampilan Depan aplikasi Absensi}

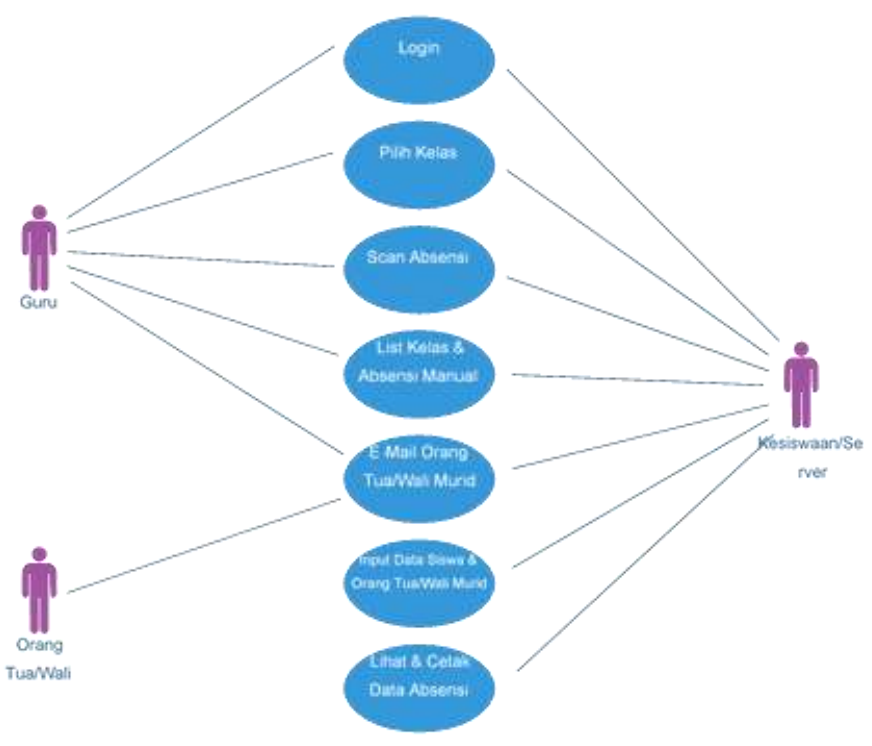

Flowchart merupakan suatu diagram yang menggambarkan alur kerja suatu sistem. Berikut flowmap yang dibuat untuk mendukung aplikasi ini.

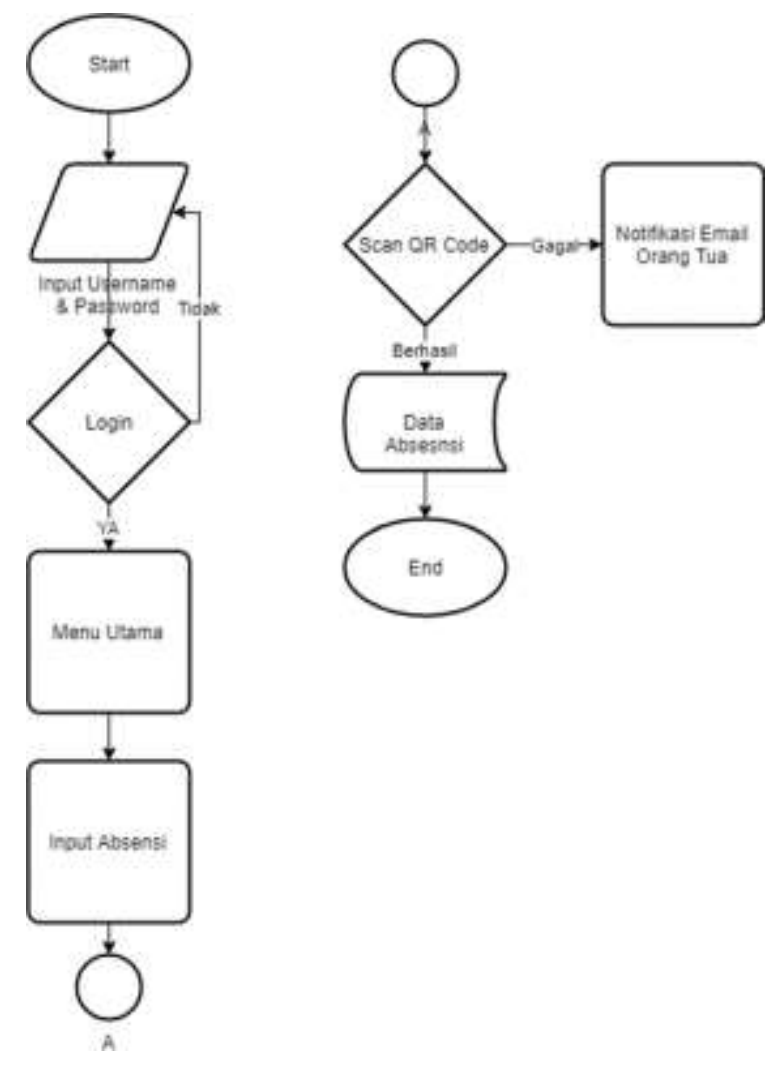

Flowchart Aplikasi Absensi.

\section{Tampilan Login Admin}

\section{$\equiv \quad \operatorname{login}$}

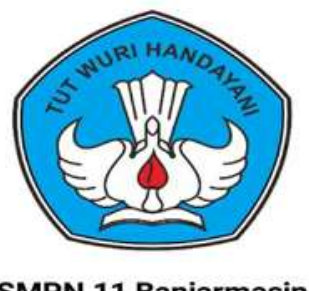

SMPN 11 Banjarmasin

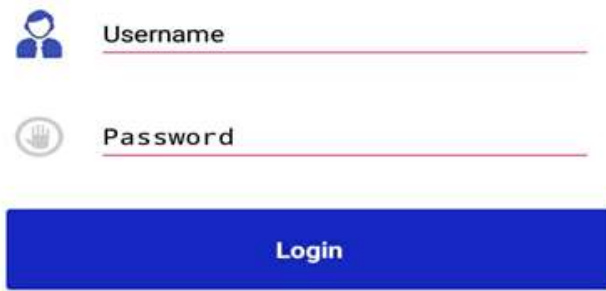

Jurnal Ilmiah "Technologia" 
Menu Utama Absensi

\section{Menu Utama}

\section{SMPN 11}

Banjarmasin
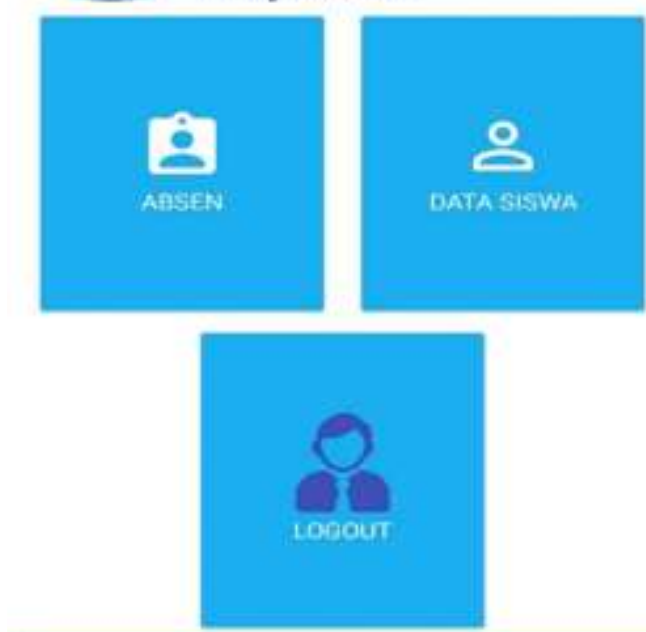

SMP Negeri 11 Banjarmasin

\section{Menu Absen Qr Kode}

\begin{tabular}{|c|c|c|}
\hline $19: 37$ & & $2,4 \mathrm{~kb} / \mathrm{d} \theta$ of all $9 \mathrm{~cd}$ \\
\hline$\equiv$ & SMPN 11 & \\
\hline
\end{tabular}
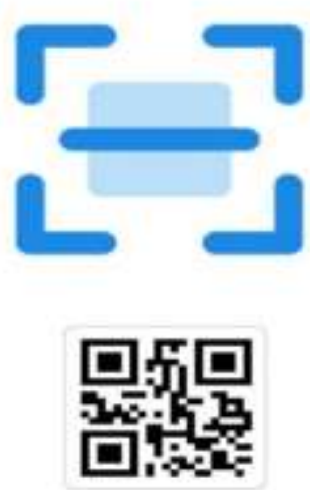

\section{ABSEN QR KODE}

Jurnal Ilmiah "Technologia"

\section{Tampilan simulasi salah satu siswa}
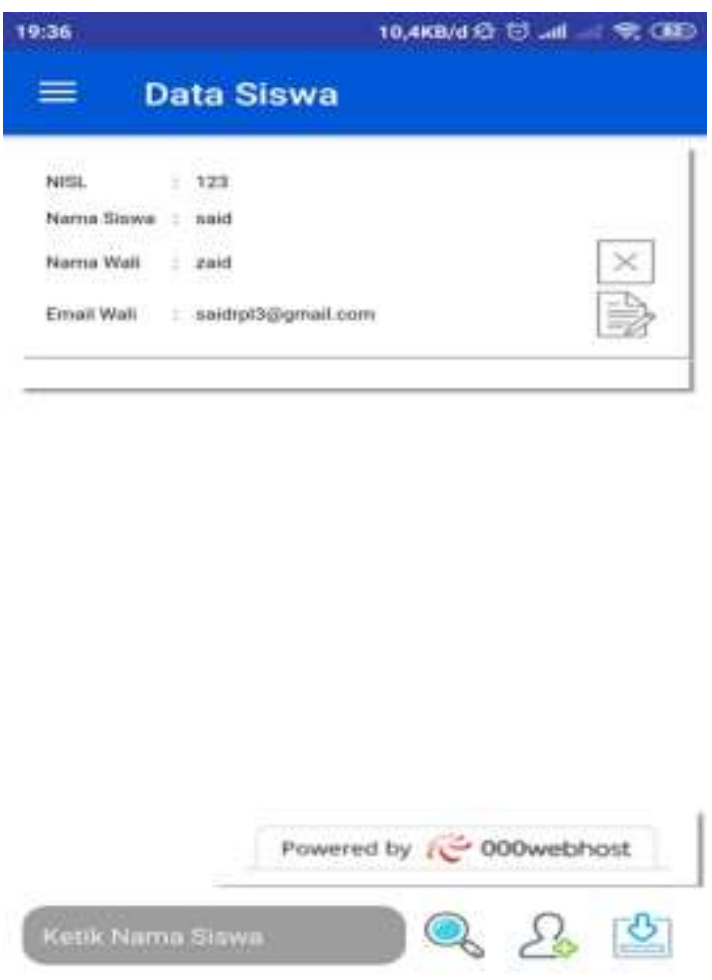

Tampilan email orang tua siswa

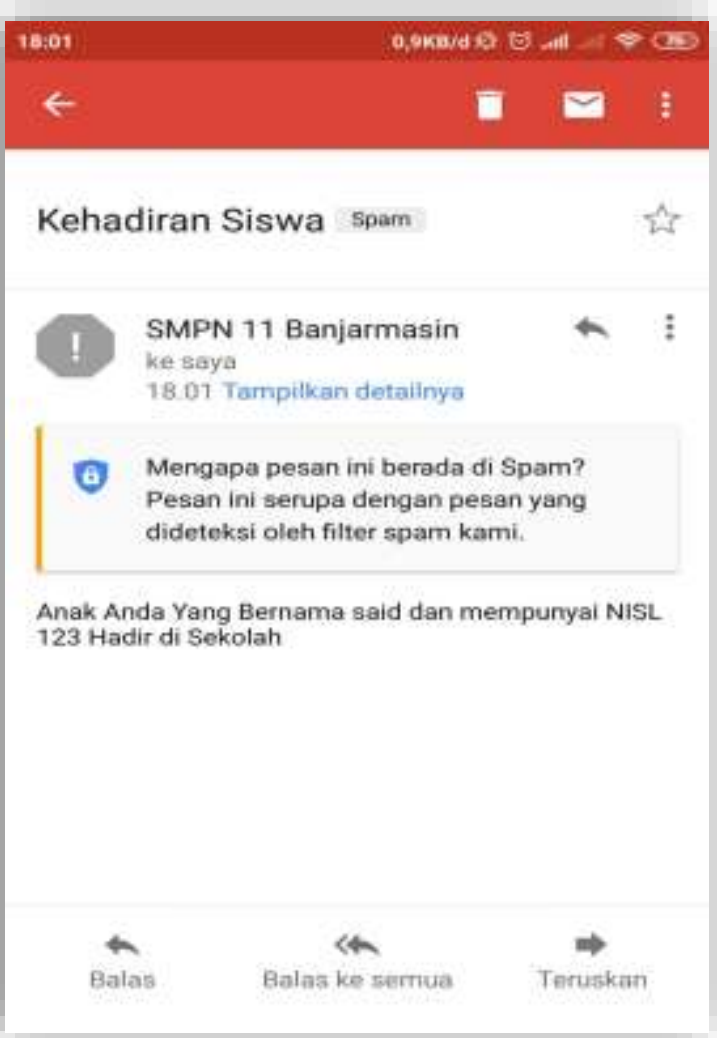




\section{KESIMPULAN}

Dengan Adanya sistem aplikasi presensi siswa menggunakan kode QR (QR Code) berbasis android di SMP Negeri 11 Banjarmasin ini diharapkan dapat mengurangi resiko kehilangan data absensi siswa yang terkadang terselip dengan berkas lain dan memberi kemudahan orang tua siswa dalam memantau anaknya disekolah, dengan aplikasi ini guru dapat melakukan absensi siswa melalui kode QR yang tertera pada kartu pelajar menggunakan smartphone android sebagai pembaca kode QR, sehingga guru tidak perlu lagi mencatat absensi siswa secara manual. Jadi guru bisa meminimalisir resiko kehilangan data absensi siswa dalam melaksanakan proses belajarmengajar.

\section{REFERENSI}

Putra, I.N.H.R. dan Muhammad Priyono Tri S (2015). Aplikasi Presensi Siswa Menggunakan Kode Qr (Qr Code) Berbasis Android Di Smk Shifa Kalipare Malang, 2-5.

Hadi Putu. 2009. Buku Sakti Nge-blog. GagasMedia. Jakarta Selatan.

Jubilee. 2010. Step by Step Ponsel Android. PT Elex Media Komputindo. Jakarta.

Pratama Widianto. 2011. Tutorial Android Programing. From greenbel : http://greenbel.wordpress.com

Ridwan Fridh Zurriyadi, Santoso Hariyono \& Agung Wiseto P. 2010. Mengamankan Single Identity Number (SIN) Menggunakan QR Code dan Sidik Jari. 2 (2): 17-20.

Rossy Cahyo, Utomo Wiranto Herry \& Wellem Theophilus. 2006. Perancangan dan Implementasi Sistem Informasi Layanan Short

Nurhidayat Jajang. dan Irawan Afrianto (2017). Pembangunan Aplikasi
Warung Indonesia Di Yangsan Korea Selatan Berbasis Android, 2-3.

Aswin Wibisurya. Pengenalan QR Code. From Binus University School Of Computer Science socs.binus.ac.id/2018/12/15/pengena lan-qr-code/

Ir. Sere Saghranie Daulay,M.Si (2018). Hubungan antara QR Code dan Dunia Industri dan Perdagangan

Lines of Communication by Craig Harmon (Helmers Publishing) The Bar Code Book by Roger C. Palmer (Helmers Publishing, ISBN 0-911261-09-5, 386 pages)

Punched Cards to Bar Codes by Benjamin Nelson (Helmers Publishing, ISBN 0-911261-12-5, 434 pages) 